\title{
ABC: How It Plays Out in A Cross-Cultural Classroom Communication
}

\author{
Liah Rosdiani Nasution \\ Department of Religious Studies \\ State Institute for Islamic Studies (IAIN) Padangsidimpuan \\ Email: liahnasution@gmail.com
}

\begin{abstract}
This article is written as part of the effort to answer the central question on cultivating a better cultural understanding of people from different backgrounds in clasroom settings and how this kind of communication is reflected in the communication of two international students on an American campus. This article uses an autobiography and biography, which respectively stand for $\mathrm{A}$ and $\mathrm{B}$, writing as methods to compare and contrast the similarities and differences between one student and another from different cultural backgrounds. These writings are then analyzed by using a cross-cultural analysis. This study is a qualitative study that uses a phenomenological approach to gather the data. The results show that both students find some aspects of their partner in the project surprising and enlightning which further lead to feelings of closer emotional connections due to their differences and similarities of experince as students of color and immigrants in an American campus. The greater implications of the findings in this article are expected to help teachers across the country to establish a culturaly responsive teaching ideas and pay greater attention to inculcating better cross-cultural communication strategies both within the classroom and outside of the classroom setting.
\end{abstract}

Keywords: Autobiographies, Biographies, Cross-Cultural Analysis, Cross-Cultural Communication.

\section{INTRODUCTION}

To begin with, this paper is mostly based on the article "Constructing third space” by Finkbeiner. In this article it is said that the ABC's of Cultural Understanding and Communication is a methodological tool that gives teachers and learners an opportunity to play an active and self-determined role in the process of learning the cultural profile of their peers (Finkbeiner, 2006). The ABC model was first coined by Schmidt who later worked collaboratively with Finkbeiner (1998) to develop methods for teachers to communicate with their students in a culturally more responsive way. The acronym itself implies the steps taken in the process of writing the paper. A stand for Autobiography, B for biography and C for Cultural Analysis, added with cultural self-analysis of differences, and communication designs for connecting school, home, and community in the future learning processes. 
In an increasingly more diverse classrooms and the ease of joining international forums nowadays, especially now in the middle of a global crisis where the learning and teaching processes are mostly conducted online, teachers are constantly expected to have better sensitivity towards their students funds of knowledge. Funds of knowledge is the historically accumulated and culturally developed bodies of knowledge and skills essential for household or individual functioning and well-being (Moll et al., 1992). This concept emphasis a new role of the teacher as a learner who try to understand their students and their families so that teachers can see the richness of students' culture and cognitive sources. Considering the fact that as a teacher, it is our job to understand something about everyone in our classroom, this is especially important for teachers because the information about students' culture at home can be used in their classrooms in order to provide culturally responsive and meaningful lessons that tap students' prior knowledge. Information that teachers learn about their students in this process is considered the student's funds of knowledge.

One of the strategies that can be used to learn students' homes cultures and cognitive resources in order for teachers to gain this kind of knowledge by establishing a cross-cultural communication. In Indonesian settings, mostly teachers and students live side beside, often in the same neighborhood. Due to the nature of Indonesian society that is very communal, it is normal to expect that teachers know their students religious, economy, and cultural background. However, certain aspects like personal situations, economic situation or historical backgrounds of the students might not be very visible in their daily lives. Establishing the so called cross-cultural communication with the students and their families can help both the teachers and the students as well as other students in the classrooms to further promote intercultural sensitivity in the classrooms.

A cross-cultural communication is a type of communication that occurs between people of different cultures (Ting-Toomey, 1999; Tubbs \& Mss, 1996; Yakin, 2005). These differences can be in the form of differences in ethnicity, religion, race, and class (SARA) which often divide Indonesia.A cross-cultural communication often appears in multicultural societies such as Indonesia, America, France, Germany and others. A multicultural society itself is a society consisting of various kinds of ethnic groups, each of which has a different cultural structure. The emergence of a 
multicultural society in Indonesia occurs because of the diversity of ethnicities, races, religions, ethnicities, and others. Indonesia is one of the most multicultural countries in the world so that our country also has a high risk of internal conflicts that arise due to the inability of its people to understand other cultures. This is where the importance of understanding cross-cultural communication lies. We need to instill positive values of intercultural communication in our society for the big goal of avoiding the conflict so that this good knowledge does not only concern academics, for example, but also the grassroots circles.

The functions of a cross-cultural communication, include, but not limited to, the followings:

1. To declare social identity through one's origin, ethnicity, religion, language, and education level.

2. To declare a social integration process. The essence of the concept of social integration is to accept the unity and unity between individuals or between groups while still recognizing the differences that each element has. In addition, one of the goals of communication is to give the same meaning to the message that is shared between the communicator and the communicant. In the case of intercultural communication involving cultural differences between communicators and communicants. Thus, social integration is the main goal of communication.

3. To broaden our horizon and knowledge. With the existence of cultural differences and communication therein, we, either directly or indirectly, participate in learning about each other's culture.

4. As a personal communication tool. A cross-cultural communication can also be a medium to vent for those of us who may have problems, and need a solution from interlocutors who may have different cultures from us.

Thus, it is not an exaggeration if cross-cultural communication skills are considered very important to be learned by our people who are so easily pitted against each other. This is because an cross-cultural communication can bridge the differences between two or more people who have different cultures (Kirkman et al., 2006; Rogers \& Thomas, 1999; Tian, 2010). In this case, the function of socialization is then to teach and introduce the cultural values of a society to another society which is absolutely 
necessary so that there is no miss-communication and misperception, for instance (Elegbe \& Nwachukwu, 2017; Merkin, 2009; Yakin, 2005).

\section{LITERATURE REVIEW}

This study is a sociocultural research that focuses upon the complexity of developing literacy within cultures of home, school, and community (Vygotsky, 1978). Research shows that good synergy between home, school and community can not only help students follow the school curriculum, but can also promote better literacy development (Erti, 2020; Turyanto, 2020). ABC activity is one of the options that can help connect these three settings. A great number of research has shown that exposure to and experiences with assignments like the $\mathrm{ABCs}$ can signicantly help realize this mission in multicultural classrooms, despite the callenges it has in an online settings and both for the teachers and students (Finkbeiner \& Lazar, 2016; He \& Cooper, 2009; Hutchinson, 2013; Masterson, 2018; Monroe \& Ruan, 2018). These studies also show that both inservice and preservice teachers can have very limited understanding about their students cultural knowledge which, in turn, can lead to students feeling of being left out or do not belong to the rest of the class.

ABCs activities which consist of writing an utobiography, biography and conducting a cultural comparison of the students can greatly minimize these feelings. The realization of these three activities can be seen in the following sequence written by the researcher in 2016 as an Internasional student at the University of New Mexico taking literacy across culture class where she got to meet many international students who, at some points in their academic journey at the same university, had felt that they were strangers and very culturally awkward when it comes to their classroom communication: 


\section{Autobiography}

My name is Liah Rosdiani Nasution. I was born in one of the cities in North Sumatra named Rantau Prapat with my twin, Diah. At the time we were born, my mom said that the moon was shining so brightly that they believe that both of us are very special. Another thing about our birth is that we were born fused. My umbilical cord was buried in the same hole with my twin's. According to the custom in my village, if that happens than the twin will be physically and emotionally too-attched to the point that they might get sick together at the same time.. Therefore, if the parents don't want to see their twin get sick together, crying together, they should separate the cords and bury them in different burrow. However, my parents did not really take what they believe as a myth so my father buried them together a week later. A week passed and my grandfather coming from a different village visited us for the first time. When he knew that our umbilical cords were buried together, he insisted my father to dig the them again and separated them in a different burrow.

My father then did that with the feeling that nothing is going to be different with our attachement to each other by doing that. However, the upcoming days, months, and years he then realized that he was wrong and my grandfather was right that we are going to be bound deeply each other. I and my twin sister are really unseparated and deeply connected to each other both physically and emotionally. When she got sick, I also got sick not long after. When she was crying for any reason, I knew that something happens to her. And the same goes for her, just like what people in my village believed. Because of this, we usually prefer to sit in the same class, wearing the same clothes almost daily, having the same food to eat and things like that. This continued up until we started our university lives where we had to finally separated since we took a different major. Although we were still together most of the time, but that was the first time when we had to learn how to take bus alone or with some other people and do other things separately.

At the age of 12 months, my father who is a primary school teacher, was transferred to a school which is located twenty minutes away from where my granny lived. Angin Barat is a very small village with mountains surrounding the village. Most of the residents do farming as a livelihood. My father, although he was financially stable at that time as a teacher with two kids, did farming as well because he had to handle 
some pieces of land given by her mother, my granny who passed away not long after we moved to Angin Barat. Because he could not manage to take advantage of all the lands given by my granny due to his responsibilities as a full time teacher, my father then decided to lend some pieces to our neighbors who needed lands to work in for their livings. This made some of my relatives jealous and prepared a cunning plan to my father. When my father got back from the rice field he was working at that day, they hit my father in the head with a piece of block so hard that he fell down from his motor cycle. The hitting was so hard that we fell from his motor bike with blood streaming down his forehead. Before falling down, however, my father begged them to not hurt me and my twin sister and to leave us alone. We were crying and screaming, not knowing why our father was beaten so severely. Not sure whether they heard him or were in a rush to finish their business, they continue to beat my father until he fell uncosncious. Even after he was motionless in the ground, they still tried to kill him who lied unconscious by beating him harder in the head and stomach. The beating only stopped because some lady saw the scene and rushed to my father's help which stopped them from doing their plans. My father then was rushed to the hospital which was 5 hours away from my village. Accompanied by some family members, my mother reported the incident to the police station and the report was processed right away soon after my father was taken care of at the hospital. The rest of this story is that a few months later, the people who plotted to kill my father became suspects and after a long waiting they were sent to jail. This story is one of my life's turning points because upon hearing the story more a few years later, we made a promise that we will try our best to make our father happy again which also influenced our academic achievements years later until we become university students. I believe that is also the reason why I consider myself as a family-oriented person.

When I finished my undergraduate program, I applied to a language training program and passed. In that program, I met friends from all over Indonesia who most of them had involved in different kinds of international students exchange program previously. This was the first time I got the idea of studying overseas. While attending the program, I researched American universities and found some that sparked my interest. After completing the program, I submitted an application to Fulbright scholarship and passed all the selection processes. My parents were so happy that they 
made a small celebration and invited my neighbors and relatives. Although my family supported my decision to study overseas, some of my relatives suggested to reconsider or even more schocking to me, reject the scholarship because it was not normal for a woman in my culture to travel that far without a companion. The concept of studying overseas for women is completely unusual, to say the least since most of the time, it is always men who study overseas. The destination of their studies is mostly Mediteranian countries like Saudi Arabia, Yaman, and others. To the US, no one has ever done that from my conservative town before especially by a girl. That is generally because people in my village tend to believe that women do not have to be well-educated because being "averagely-educated" can also give them the life they want as long as they "behave" as good girls and follow their parents' insights on almost everything. Thus, pursuing the highest degree of education is pointless, for that matter. Part of it also that people in my village considered that Americans are mostly very individualistic, racist, and unwelcoming to foreigners like me. Bad things can happen anytime and with no family around, the situation can be worse. They were also concerned that i might be "different" in a negative sense due to the influences from friends or people I hang out with in the US. However, I rejected those ideas by saying that racist people are everywhere, even in Indonesia and that we can always be ourselves in any environment since it clearly depends on the individual. If someone is faithful with her tradition, religion, or anything she will still become her old self. Moreover, if the influence is good, then why not? Another reason why it was controversial is because a girl in my age, 23 years old, was supposed to be married or preparing herself for a marriage instead of continuing her study to a higer level which I completely turned down by saying that education was my priority at that time. I dont mind getting married much later on as long as I can get my education now. In Indonesian culture, everyone is related to everyone so it felt like the whole village oppose my ideas of studying abroad. However, my father who was very happy about the scholarship told people that he would support me regardless of what others think about my decision. That was what made me strong at that time until I am finally here. I really thank God for having a very supportive father. My father has always been the greatest supporter in my life.

During the time I live in Indonesia, I learn that different place has some different sets of culture. That is always true considering that Indonesia is an island country with 
more than 700 islands spreading over the archipelago. Indonesia is one of the most diverse country in terms of languages spoken, traditions and customs, food, or religion, among many others. However, USA is much more diverse since people from all over the world come and stay in the US which makes it very unique to Indonesia. USA with this quality teaches me that it is very important to be adoptable. Although I have to say that it is not very easy to adopt to a new culture, but I believe people can learn it gradually. I now try to understand many rich points I encounter in my daily experiences that sometimes make me feel that I am a complete stranger in my own environment. The first time I came here, I found out that people always greeted me with "Hi, How are you?" which is weird to me because people in Indonesia do not normally say that to people they don't know. In trying to response that, I awkwardly asked people back "I am sorry, are you talking to me?" with a puzzle look on my face. For those people who greeted me, my question might sound stupid but I genuinely surprised to know that I was the one they greeted. I also had confusions on so many things I did not understand that makes my culture shock experience was even worse at the very beginning of my life here.

Despite the many difficulties in my academic journey, however, I am now very grateful that I managed to deal with all of them. I learned that no matter how confusing the experiences are, they are still the best way to learn the culture of this country. With this mind, I feel more positive towards all the experiences I found here. Another thing I learned is that I now started to constantly compare Indonesian culture and American culture which lead me to pick the "good" and "bad" sides of these cultures and began to develop "a new culture", which contains the standard and value I selected from both cultures. By doing this, I found that my culture shock is getting better because I can go back and forth to and from my Indonesian culture and the American culture I am curently living in.

\section{Biography}

Andrea Enciso was born in one of the largest cities in Mexico, Gudalajara where she lived with her three siblings, grandparents, and mom who supported them. She was a student in one of the Mexican school when her mom moved to US and began working at a restaurant and cleaning houses while also taking care of her cousin afterschool to earn enough money. She was very sad for being away from her mom that she became 
silent and unconfident. This is because her mom loved her so much that she made it clear that her only responsibility at that time is studying, nothing else. Not even helping with household tasks. She lost support at that time.

Fortunately, after her mom was staying awhile in US, her aunt convinced her mom to stay permanently and so at the beginning of the fifth grade, Andrea moved to New Mexico to stay with her mom. She is the only one who stays with her mom in New Mexico. Her three other siblings are all in Mexico. This is according to her because she is the youngest daughter of her mom. This was happened a few months after her mom got married to a New Mexican man.

In New Mexico, they lived in a small town called White Rock which was part of Los Alamos, New Mexico. Their house is very large, like the ones she had only before seeing them in movies. After about a month, her mom and her stepdad convinced her to start going to school. She was the only Non - English speaker in her class at that time so she received a lot more attention from her teachers, classmates, and the rest of staff at the school. Everybody was extremely helpful and supportive towards her but she often felt overwhelmed and was not very cooperative at home or school. At home, she was constantly being checked by her father, she had chores, she had to attend school every day. She was discouraged from speaking Spanish and was only allowed to watch TV for a few hours a day. At school, she was given chapter books to read, after school activities to attend and she was expected to talk about herself and her feelings constantly. This new academic culture are different from the one she had before. She met many new and different people in terms of their cultural, educational, or geographical background since then. Although it was difficult at first, she realized that all of them were healthy, positive that have taught her a lot throughout the years but at the time, she had to make drastic adjustment to the way she acted. She really appreciates being in such environment that can help her learn about other people better. That improves her confidence both in academic and social settings.

Soon enough however, she began to integrate to her new community and even started to think of it as her own. The problem, she now realizes, was that she also began to leave her old culture behind. She was in a way, even embarrassed that she came from somewhere that is different from anybody else. It wasn't until she was in High School when she saw how some of her foreign friends struggled here that she realized how 
important it is not to forget our language and our "old" culture because that is all part of our identity and we should welcome it rather than forget about it.

At school, Andrea was a member of a group of students that gathered at the club were from different places but somehow felt like they belonged together. The welcome she received regardless of where we came from and our lack of global knowledge was like no other. In that group, they all have the opportunity to share stories about them and learn about others. She fell in love with every single culture that was part of that club and she realized that she was eager to learn all that she could about them.

Ever since Andrea began to appreciate diversity greatly and maintain her own. She can now say that she is just as much Mexican as she is American and she is proud to call both of these places her homes. Now that she is studying to be a teacher, she hopes she can help her students to be proud of their cultural background by making them feel welcomed as individuals so that they do not have to forget any part of their identities.

Now that she lived in New Mexico for about eight years, she feels that she is a New Mexican now. She now has many friends, boyfriend, and relatives from her father family. All these people helped her feeling like home, not in somewhere new anymore.

\section{METHODS}

Based on a review of previous studies, this research aims to develop a conceptual framework on how the cross-cultural communication can be cultivated in multicultural and diverse classroom settings. This study is of qualitative research in nature that uses a pehnomenological approach to describe the participant's experience. This study tries to answer the following question: how does the ABC activity improve students' understanding about their peers in classroom?

The data in this study was collected thorugh interviews with the participant to learn about her experiences and perspectives in greater detail. The following list summarizes the steps and processes taken in this study:

1. Planning and formulating the data that include transcribing interviews

2. Examining the data for potentially emerging patterns

3. Establishing a set of codes that to clasify the data. 
4. Designating codes to the data by going through the responses and tagging them with codes in a spreadsheet

5. Determining recurring themes and connecting codes together into themes.

\section{RESULTS AND DISCUSSION}

\section{Cross-Cultural Analysis}

Upon investigating the patterns arise from the data, the analysis is set to focus on the differences and similarities of both students as presented on the following cultural venn diagram:

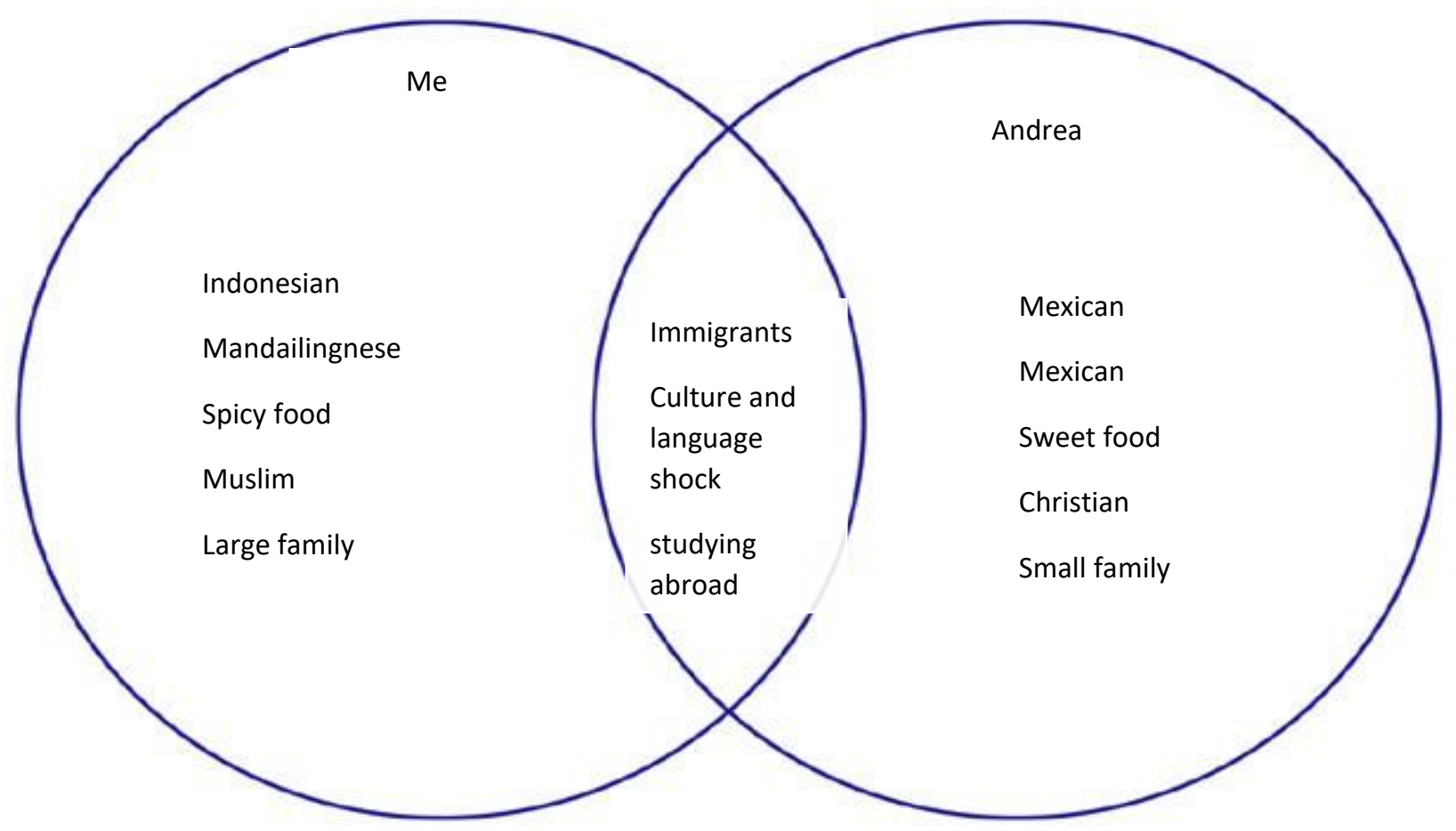

In the first part, I found some difficulties in writing the autobiography because I

feel that there are so many important things that happened in my life that makes me "me today". I am fully aware that who I am today is an accumulation of everything happens in my live. Thus, it is quite difficult to summarize it in a three or four-page story. However, since the instruction told me to think about specific experiences which contributed to who I am now, I tried to picks some major aspects and link them to my today's me version. 
The second part is the biography. When I read the biography written by my buddy Andrea Enciso, I found that it is also difficult to say that anything she mentioned is false. I personally think that the reason is because when we interview someone, we tend to believe that she is from different culture thus live with that culture. I define this as an ethnographic approach. The ethnographic approach is when we are open to other cultures and communities on their own terms in which we do not apply our own beliefs and values to their system (Agar, 2006). The biography written by Andrea is not wrong, it is just not complete. Furthermore, the biography portrays the perspective of the other on the self. It makes both participants become aware of the different perspectives of the self which have been expressed in the autobiography and in the biography (Finkbeiner, 2006). Thus, I personally think that there is no such wrong term in biography. However, if it is incomplete, I realize that that is the result of the information I gave her which is maybe incomplete too. It is difficult to tell someone everything about our lives in just a few hours. I also do not see any contrasting or surprising points in the biography written by Andrea.

This condition also happens to Andrea. When asked whether something I mentioned in her biography is untrue, she said nothing except it is incomplete. However, I have to say that I am surprise to know that Andrea has a strong bond with both the cultures she lived in, Mexico and America. This strong bond can be seen when for example she said that she has no specific plan whether to stay in America or going back to Mexico later upon the completion of her study. This is because she said she likes to consider both countries as home. She even wants to have dual citizenship so she does not have to choose one of them. For me personally, this is surprising because although we both are immigrants, but I never had the idea to stay in America. Although I like America, but I know that I will go back to my homeland later on.

Another thing that I like to consider about Andrea is that she is the favorite child in her family. This can be seen from the fact that although she has three other siblings, none of them are living with her mom. The three of them are living in Mexico on their own and she is the only one who lives with her mom. When asked why, she said that she does not really know the reason. She was just happy to not be away from her mother but never really wonder why the other siblings are not asked to come to live with their 
mom too. When I told her about this, she was very surprised, clearly seen from "Really? I don't know that. But you are probably right" look she gave me.

When considering the elements of our biographies, we found the following similarities:

We are both immigrants, both are experiencing culture and language shock when first arrived in Albuquerque, both are fascinated with studying abroad idea. These similarities make us feel become a real friend instead of classmates. This is very important because the communication between us also become more casual. I can see deeper aspects of her.

In terms of differences, we also see that we both are from different cultural background, America and Asia. Both speak different L1, both like different types of food, both have different religions, and both have different family situation.

When considering the table of target and non-target groups, it can be seen that Andrea and I are very similar in terms of oppression. We are oppressed in terms of racism, sexism, lookism, and language. Furthermore, we are privilege in terms of classism, heterosexism, ableism, ageism, adultism, rankism/ elitism, and transphobia terms. As for the religious part, as a muslim I found myself oppressed and Andrea is privileged with her Christianity. However, after reviewing the table of target and nontarget group, we realize that the answers can be different if it applies in different country or culture. Take for example, in Indonesia the privileged religion is Islam, but it is oppressed here in USA or in some other countries. The same happens with racism, lookism, rankism, immigrant status, and language. So again, it really depends on the cultural background applied to it although I have to say that there are some type of oppressions that are same everywhere like ageism, or financial condition for example.

The steps we undertook during the making of this paper has greatly contributed my insight of creating the third space. It is true that from the interview and review of the biography for example, I found that the ABC's seem to initiate a process which makes participants step out of the dualism of existing worlds and create a new Third Space (Finkbeiner, 2006). I am happy for being able to learn someone in a deeper and personal level by doing this paper. As a future teacher, I am also excited knowing that I can use this ABC's model to build third space in class because The ABC's have become a 
highly appropriate approach for the foreign language classroom, because they allow for independent work with texts generated by the learners themselves.

Finally, although I realize that the goal of the ABC paper is to create a third space and to realize one's ethnocentricity is not complete yet. But still, it is very good to learn something about other people. I value all the process I took to know Andrea Enciso better. To conclude all, I would like to personally note that it is true that many people (a) are both "locals" and "foreigners" somewhere in the world, depending on the location and the perspective they are in , (b) continuously meet new people, (c) may encounter intercultural events while they are making other plans, (d) must be prepared for facing differences and similarities as they spontaneously happen in the global village.

For teachers who are situated in a culturally diverse classroom and have goals in creating a culturally more sensitive and conducive learning environments, here are some teaching ideas that can be established from the above ABC activities:

1. To continusly learn about all the members of the class.

2. To have a personal conversation with students once in a while in an attempt to understand more about their home and community situations. This is especially important since these two settings might provide answers about students' conducts at school.

3. To bring and discuss real world problems that happen in students' community or homes. This can be done by connecting the lesson with these problems

4. Acknowledging students' funds of knowledge by integrating their culture with the lesson presented in the classes.

5. To bring in guest speakers who can speak about their experiences in classes.

\section{CONCLUSIONS}

Teachers have the respponsibilities to create a culturally friendly classroom and learning environment and this can be achieved thorugh the use of ABC activities as presented by the result of this study. The ABCs methods is a proven method that can be used to establish a better cultural competency and sensitivity in the classroom communications both between teachers and the students because both parties can get to know each other better which in turn can help establish maximize the teaching and learning processes 
and results. This also helps to better connect the school, home and community which in turn can improve students' appreciation and cultural understanding towards and of others. Thus, these activities can be applied to help create a culturally more conducive learning environments, both in online and offline settings.

\section{REFERENCES}

Agar, M. (2006). Culture: Can you take it anywhere? International Journal of Qualitative Methods, 5(2), 1-12.

Elegbe, O., \& Nwachukwu, I. (2017). A cross-cultural analysis of communication patterns between two cultures in Southwest Nigeria. Journal of Humanity and Social Sciences, 9.

Erti, M. T. (2020). Pen ingkatan Kemampuan Guru dalam Melaksanakan Problem Based Learning m elalui Supervisi Akademik d i Sekolah. Indonesian Journal of Instructional Media and Model, 2(1), 5 1-58.

Finkbeiner, C. (2006). Constructing third space: The principles of reciprocity and cooperation. In $A B C$ 's of cultural understanding and communication: National and international adaptations (pp. 19-42). CT: Information Age.

Finkbeiner, C., \& Lazar, A. (2016). Getting to Know Ourselves and Others Through the ABCs: A Journey Toward Intercultural Understanding. Information Age Publishing.

He, Y., \& Cooper, J. (2009). The ABCs for pre-service teacher cultural competency development.Teaching Education. Teaching Education, 20(3), 1-305.

Hutchinson, J. (2013). Communication models of institutional online communities: The role of the ABC cultural intermediary. Journal of Media and Communication, $85(5), 1-75$.

Johnson, A. G. (2006). Privilege, power, and difference. McGraw Hill.

Kirkman, B. L., Lowe, K. B., \& Gibson, C. B. (2006). A Quarter Century of “Culture's Consequences": A Review of Empirical Research Incorporating Hofstede's Cultural Values Framework. Journal of International Business Studies, 37(3), 285320.

Masterson, M. (2018). Self-Discovery Through the Experiential Co-Construction of Life Storiesin the Foreign Language Classroom. Journal of Experiential 
Education, 41(4), 341-355.

Merkin, R. (2009). Cross-cultural communication patterns - Korean and American Communication. Human Communication, 12(2), 199-213.

Moll, L., Amanti, C., Neff, D., \& Gonzalez, N. (1992). Funds of knowledge for teaching: Usinga qualitative approach to connect homes and classrooms. Theory into Practice, 31(2), 132-141.

Monroe, L., \& Ruan, J. (2018). Increasing early childhood preservice teachers' intercultural sensitivity through the ABCs. Journal of Early Childhood Teacher Education, 39(1).

O’Brien, T. (2019). Bringing Cross-Cultural Communication Analysis Into Foreign Language Classrooms. In Intercultural Foreign Language Teaching and Learning in Higher Education Contexts (pp. 71-97). https://doi.org/https://www.researchgate.net/deref/http\%3A\%2F\%2Fdx.doi.org\%2 F10.4018\%2F978-1-5225-8128-4.ch004

Rogers, E. M., \& Thomas, M. (1999). Steinfatt. Intercultural Communication. Waveland Press, Inc.

Tian, J. (2010). A Comparative Study of Chinese and American Cultural Context and the Influence on Communication. Journal of Language Teaching and Research, $1(4), 524-526$.

Ting-Toomey, S. (1999). Communicating Across Cultures. The Guilford Publications, Inc.

Tubbs, S. L., \& Moss, S. (1996). Human Communication: Konteks-konteks Komunikasi. Remaja Rosdakarya.

Turyanto, J. (2020). Peningkatan Keaktifan d an Hasil Belajar Siswa melalui Penerapan Strategi Pembelajaran Guided Note Taking Bervariasi p ada Mata Pelajaran PKn. Indonesian Journal of Instructional Media and Model, 2(1), 59-77.

Vygotsky, L. . (1978). Mind in society: The development of higher mental process. Harvard University Press.

Yakin, M. A. (2005). Pendidikan Multikultural: Crosd-Cultural Understanding untuk Demokrasi dan Keadilan. Pilar Media. 